UDC: 351

DOI: https://doi.org/10.32689/2617-

2224-2019-4(19)-285-302

Федоренко Тетяна Анатоліївна, аспірант кафедри сочіальної $i$ гуманітарної політики, Національна академія державного управління при Президентові України, 03057, м. Київ, вул. Антона Цедіка, 20, тел.: (044) 48121 55; e-mail: tfdoctor@ukr.net

ORCID: 0000-0003-1175-6404

Федоренко Тетьлна Анатольевна, аспирант кафедры сочиальной и гуманитарной политики, Национальная академия государственного управления при Президенте Украины, 03057, г. Киев, ул. Антона Цедика, 20, тел.: (044) 48121 55; e-mail:tf-doctor@ukr.net

ORCID: 0000-0003-1175-6404

Fedorenko Tatyana Anatolievna, postgraduate student of the Department of Social and Humanitarian Policy, National Academy of Public Administration under the President of Ukraine, 03057, Kyiz, Str. Antona Tsedika, 20, tel .: (044) 481 21 55; e-mail:tfdoctor@ukr.net

ORCID: 0000-0003-1175-6404

\title{
МІНІСТЕРСТВО ОХОРОНИ ЗДОРОВ'Я УКРАЇНИ У МЕХАНІЗМІ ВЗАЕМОДІЇ З ГРОМАДСЬКІСТЮ 3 ПИТАНЬ ФОРМУВАННЯ ТА РЕАЛІЗАЦІї ДЕРЖАВНОЇ ПОЛІТИКИ У СФЕРІ МЕДИЦИНИ
}

Анотація. Досліджено проблеми теорії та практики функціонування Мiністерства охорони здоров'я України у механізмі взаємодії з громадськістю з питань формування та реалізації державної політики у сфері медицини у трансформаційний період. Проаналізовано функції та повноваження Міністерства охорони здоров’я України щодо залучення інститутів громадянського суспільства та соціально активних громадян (громадськості) до удосконалення законодавства та управлінської практики у сфері охорони здоров’я та проведення медичної реформи в Україні у 2016-2019 рр.

Досліджено основні суб'єкти, які забезпечують дієвість партисипаторної демократії у сфері охорони здоров’я в Україні. Зокрема, висвітлено проце- 
си організаційно-управлінських трансформацій підрозділів Міністерства охорони здоров’я України, які забезпечують залучення громадськості до проведення медичної реформи. Обгрунтовано висновок, що в подальшому можливим і бажаним було б створення у структурі МОЗ України відділу (експертної групи) щодо взаємодії з громадськістю у сфері формування та реалізації галузевої державної політики в складі існуючих директоратів. Наприклад, в Директораті стратегічного планування та євроінтеграції.

Узагальнено та систематизовано основні методи і форми взаємодії Мiністерства охорони здоров'я України у механізмі взаємодії з громадськістю 3 питань формування та реалізації державної політики у сфері медицини. Наголошено, що організаційно-управлінський механізм залучення громадськості до формування та реалізації державної політики у сфері охорони здоров'я в Україні буде неповним без диференціації інститутів громадянського суспільства в медичній сфері на лікарські організації (асоціації); пацієнтські організації; правозахисні організації, з чітким усвідомленням диференціації інтересів кожної з названих груп громадських організацій, а також без розуміння, що повноцінними акторами цієї системи в Україні, прямо чи опосередковано, виступають політичні еліти і представники фінансово-промислових груп і бізнесу у сфері надання медичних послуг, фармакології та медичного страхування.

Ключові слова: охорона здоров'я, державна політика у сфері охорони здоров'я, Міністерство охорони здоров'я України, громадськість, інститути громадянського суспільства, партисипаторна демократія.

\section{МИНИСТЕРСТВО ОХРАНЫ ЗДОРОВЬЯ УКРАИНЫ В МЕХАНИЗМЕ ВЗАИМОДЕЙСТВИЯ С ОБЩЕСТВЕННОСТЬЮ В ВОПРОСАХ ФОРМИРОВАНИЯ И РЕАЛИЗАЦИИ ГОСУДАРСТВЕННОЙ ПОЛИТИКИ В СФЕРЕ МЕДИЦИНЫ}

Аннотация. Исследованы проблемы теории и практики функционирования Министерства охраны здоровья Украины в механизме взаимодействия с общественностью по вопросам формирования и реализации государственной политики в сфере медицины в трансформационный период. Проанализированы функции и полномочия Министерства охраны здоровья Украины в сфере привлечения институтов гражданского общества и социально активных граждан (общественности) к процессам усовершенствования законодательства и управленческой практики по вопросам охраны здоровья и проведения медицинской реформы в Украине в 2016-2019 годах.

Исследованы основные субьекты, обеспечивающие действенность партисипаторной демократии в сфере охраны здоровья в Украине. В частности, освещены процессы организационно-управленческих трансформаций подразделений Министерства охраны здоровья Украины, которые обеспечивают привлечение общественности к проведению медицинской реформы. Обосновано вывод, что в дальнейшем возможным и желательным было бы создание в структуре МОЗ Украины отдела (экспертной группы) по взаи- 
модействию с общественностью в сфере формирования и реализации отраслевой политики в составе существующих уже директоратов. К примеру, в Директорате стратегического планирования и евроинтеграции.

Обобщены и систематизированы основные методы и формы взаимодействия Министерства охраны здоровья Украины в механизме взаимодействия с общественностью по вопросам формирования и реализации государственной политики в сфере медецины. Акцентировано внимание на том, что организационно-управленчиский механизм привлечения общественности к формированию и реализации государственной политики в сфере охраны здоровья в Украине будет неполным без дифференцации институтов гражданского общества в сфере медицины на врачебные организации (ассоциации); пациентские организации; правозащитные организации с четким определение интересов каждой из названных групп общественных организаций, а также без осознания, что полноценными акторами этого механизма в Украине, прямо или опосредовано, выступают политические элиты и представители промышленно-финансовых групп в сфере предоставления медицинских услуг, фармакологии и медицинского страхования.

Ключевые слова: охрана здоровья, государственная политика в сфере охраны здоровья, Министерство охраны здоровья Украины, общественность, институты гражданского общества, партисипаторная демократия.

\section{MINISTRY OF HEALTH OF UKRAINE IN THE MECHANISM OF INTERACTION WITH THE PUBLIC ON ISSUES OF FORMATION AND IMPLEMENTATION OF STATE POLICY IN THE FIELD OF MEDICINE}

Abstract. The publication is devoted to the study of the problems of the theory and practice of functioning of the Ministry of Health of Ukraine in the mechanism of interaction with the public on issues of the formation and implementation of state policy in the field of medicine during the transformation period.

The functions and powers of the Ministry of Health of Ukraine regarding the involvement of civil society institutions and socially active citizens (the public) in improving legislation and management practices in the field of health care and conducting medical reform in Ukraine in 2016-2019 are analysed.

The main subjects that provide the effectiveness of party-side democracy in the healthcare sector in Ukraine are studied. In particular, the processes of organizational and managerial transformations of the subunits of the Ministry of Health of Ukraine are investigated, which ensure the involvement of the public in the implementation of medical reform. The conclusion is substantiated that in the future it would be possible and desirable to create in the structure of the Ministry of Health of Ukraine a department (expert group) on interaction with the public in the field of formation and implementation of sectorial state policy within the existing directorates. For example, in the Directorate of Strategic Planning and European Integration. 
The main methods and forms of interaction between the Ministry of Health of Ukraine in the mechanism of interaction with the public on the issues of formation and implementation of state policy in the field of medicine are generalized and systematized. It is noted that the organizational and managerial mechanism of involving the public in the formation and implementation of state policy in the field of health care in Ukraine will be incomplete without differentiating civil society institutions in the medical sphere into medical organizations (associations); patient organizations; and human rights organizations with a clear understanding of the differentiation of the interests of each of these groups of civic organizations, as well as without understanding that the political actors and representatives of financial and industrial groups and business in the field of providing medical services, pharmacology and health insurance.

Keywords: health care, public health policy, the Ministry of Health of Ukraine, public, civil society institutions, participatory democracy.

Постановка проблеми. Загальновідомо, що здорова нація в XXI ст. є пріоритетною цінністю для успішного розвитку сучасної держави й суспільства. Адже, зовнішньополітичні, економічні, фінансові, військові і інші ресурси кожної з держав світу ефективно функціонують та примножуються лише за рахунок “людського капіталу”. Останній передбачає не лише демографічні, освітні та професійні показники, а й здоров'я нації, забезпечення якого не можливе без ефективної системи державного управління у цій сфері суспільних відносин.

Системи охорони здоров'я в усіх державах світу залишаються одними 3 найбільш динамічних i, одночасно, найбільш чутливих соціальних систем. Отже, на сьогодні складно виокремити якусь одну, зразкову систему державного управління у сфеpi охорони громадського здоров'я, що можна постати за вдалий приклад для інших країн і може бути безза- стережно та вдало імплементованою в них.

Якщо в одних державах світу медичні реформи одноразово трансформували системи державного управління у сфері охорони громадського здоров'я у зразкові (Велика Британія в 1948 р. одномоментно започаткувала роботу Національної служби охорони здоров'я), то в інших - вони мають перманентний характер, коли кожен новий уряд змінює ціннісні орієнтири, стратегію та підходи до реформування державного управління у сфері охорони суспільного здоров'я. Подібна ситуація була характерною й для України, до започаткування в 2016 р., триваючої й сьогодні, масштабної медичної реформи, результатами якої уже є якісні трансформації первинної ланки надання медичних послуг і створення Національної служби охорони здоров'я в $2017 \mathrm{p}$.

Водночас, в усіх випадках державне управління у сфері охорони здо- 
ров’я, а також проведення медичних реформ, буде ефективним лише за умови підтримки суспільством, взаємодії профільного міністерства 3 громадянським суспільством в особі його інститутів - громадських організацій, профспілок, соціальних мереж тощо. Так, Г. Мінцберг у своїй праці “Міфи про охорону здоров’я. Як не помилитися, реформуючи медичну систему" (2017), аналізуючи основних гравців надання послуг у сфері медицини, виводить чотири основні квадранти, що “... відповідають чотирьом геть різним світам лікарні й називаються лікування, піклування, контроль та спільнота" [1, с. 113]. На думку Г. Мінцберга, до останнього компоненту механізму охорони суспільного здоров'я слід віднести професійні асоціації медиків, які контролюють поведінку своїх членів, “.. залучену спільноту всіх штибів, разом із групами захисників (наприклад, із прав пацієнтів) та різноманітні асоціації, пов'язані зі здоров'ям" [1, с. 113].

Можемо в цілому погодитись із позицією Г. Мінцберга, що спільнота, в широкому сенсі цієї категорії, є важливим складником системи охорони здоров'я будь-якої держави світу, включно з Україною, і вона охоплює самі різноманітні інститути громадянського суспільства: від саморегулівних лікарських організацій (Асоціація стоматологів України та ін.) до пацієнтських організацій, а також профспілок, організацій роботодавців, профільних громадських організацій, які спеціалізуються як на правозахисній діяльності, так і на підтримці медичних реформ, ЗМІ тощо. Ці та інші асоціації громадян, як лікарів, так і пацієнтів, а також інших соціально активних громадян, не байдужих до проблем медицини, впливають на стан і розвиток медицини. Їх взаємодія з міністерством, що формує й реалізує державну політику у сфері охорони здоров'я та проводить медичні реформи, є надзвичайно важливою, що зумовлює необхідність наукового обгрунтування відповідних управлінських механізмів і акцентів ї функціонування. У нашому дослідженні це буде місія Міністерства охорони здоров’я України у механізмі взаємодії з громадськістю з питань формування та реалізації державної політики у сфері медицини у трансформаційний період.

\section{Аналіз останніх досліджень} i публікацій. Проблеми теорії та практики публічного управління у сфері охорони здоров'я в Україні є традиційним предметом досліджень науки державного управління, й висвітлювалися такими дослідниками, як М. Банчук [2], М. Білинська [3], Н. Васюк [4], В. Григорович [5], В. Князевич [3], Т. Попченко [6], Н. Рингач [7], Л. Усаченко [8], О. Федько [9], Н. Ярош [3] та ін.

Не менш актуальною для науковців залишається й проблематика взаємодії органів державного управління з інститутами громадянського суспільства у процесі формування та реалізації різних секторів державної політики в Україні. Адже, як справедливо зазначає О. Пухкал, “Як дві складові єдиної суспільної системи громадянське суспільство і держава у своєму розвитку взаємообумовлюють одне одного" [10, с. 1].

Разом 3 тим, проблематика взаємодії Міністерства охорони здоров’я 
України, як основного провайдера медичної реформи 2016-2019 рр., із громадськістю, досліджувалася в Україні лише фрагментарно. До того ж, в останні роки кількість публікацій в Україні на цю тематику зменшилась.

Метою статті $є$ визначення міciї та функціонування Міністерства охорони здоров'я України у механізмі взаємодії з громадськістю з питань формування та реалізації державної політики у сфері медицини у трансформаційний період, а також обгрунтуванню пропозицій щодо удосконалення відповідної публічно-управлінської діяльності.

Виклад основного матеріалу. Охорона здоров’я людей є однією 3 найбільш важливих і чутливих сфер життєдіяльності суспільства та держави, предметом їх обопільно вигідної співпраці. Адже здоров'я окремої людини і суспільства в цілому є визначальним параметром потенціалу людського капіталу кожної держави світу та важливим індикатором успішності її політичного, соціально-економічного та культурного розвитку [11, с. 113]. Як і в другій половині XX ст., на сьогодні вагома місія в забезпеченні збалансованої політики у сфері охорони здоров'я належить державі в особі їі спеціально уповноважених органів, якими традиційно $€$ міністерства охорони здоров'я. Не є винятком з цього правила й Україна.

Нині Міністерство охорони здоров'я України, на наш погляд, цілеспрямовано реалізує системні заходи щодо залучення громадськості до формування та реалізації державної політики у сфері охорони здоров'я та проведення медичної реформи у 2016-2019 рр. Це зумовлюється тим, що рельєфні зміни у сфері управління охороною здоров'я, які реалізуються в Україні, потребують, поперше, роз'яснення їх мети, сутності, змісту та кінцевих результатів, а також їх індикативних показників для головних суб'єктів відповідних реформ - громадян-пацієнтів і громадян-лікарів; по-друге, забезпечення зворотного зв'язку між уже згаданими споживачами і авторами медичної реформи.

На користь наведеного висновку свідчать і матеріали, надані Міністерством охорони здоров'я України (Лист Міністерства охорони здоров'я України від 03.03.2018 р. № $\quad$ 16-20/Ф-2053/124/2887-зв) (далі - Лист МОЗ) на наше звернення від 07.02.2018 (№ Ф-2053) в частині запиту інформації про “досвід залучення Міністерством охорони здоров'я України громадськості, зокрема інститутів громадянського суспільства (громадські організації, волонтерські організації, лікарські та пацієнтські організації тощо), до формування та реалізації державної політики у сфері охорони здоров'я та до проведення вкрай важливої для суспільства медичної реформи” [12].

У попередніх публікаціях ми неодноразово зупинялися на аналізі окремих положень цього Листа МО3, зокрема 3 питань повноважень Міністерства охорони здоров'я України, включаючи повноваження в сфері взаємодії з інститутами громадянського суспільства, організації роботи зі зверненнями громадян $\mathrm{i}$ взаємодії з профільними громадськими організаціями, профспілками тощо [11; 13-15]. Разом 3 тим, фрагментарність цих публікацій вима- 
гає систематизації викладених у них висновків, положень і пропозицій 3 метою комплексного розв'язання питання про призначення Міністерства охорони здоров'я України у механізмі взаємодії з громадськістю з питань формування та реалізації державної політики у сфері медицини у трансформаційний період.

Відповідно до частини першої ст. 6 Закону України “Про центральні органи виконавчої влади”, будь-яке міністерство є:

“... иентральним органом виконавчої влади, який забезпечує формування та реалізує державну політику в одній чи декількох визначених Кабінетом Міністрів України сферах, проведення якої покладено на Кабінет Міністрів України Конституцією та законами України” [17].

При цьому, цитований Закон України “Про центральні органи виконавчої влади” лише двічі згадує громадськість: у ст. 12 покладає на патронатні служби міністерств організацію зв'язків з громадськістю, а у ст. 14 передбачає входження до складу колегій міністерств представників громадських об'єднань [17]. На практиці ж кожне міністерство організовує сталу роботу з громадськістю, суб'єкти, методи і форми якої визначаються в положеннях про ці міністерства, затверджених постановами Уряду України.

Успіх взаємодії громадянського суспільства в особі як організаційно оформлених інститутів громадянського суспільства (громадські організації, включаючи лікарські, пацієнтські, правозахисні та ін.; профспілки, організації роботодавців, 3МІ та ін.), так і соціально активних громадян, які ситуаційно об'єднують свої зусилля для сприяння або ж протидії медичній реформі, 3 Міністерством охорони здоров'я України у сфері формування та реалізації галузевої державної політики значною мірою залежить від ефективності підрозділів міністерства, уповноважених реалізовувати відповідні завдання, функції та повноваження МОЗ України.

Відповідно до п. 5 Положення про Міністерство охорони здоров’я України, затвердженого Постановою Кабінету Міністрів України від 25 березня 2015 р. № 267, МОЗ України, 3 метою організації своєї діяльності, забезпечує в межах повноважень, передбачених законом:

“...залучення громадян до участі в управлінні державними справами, ефективну взаємодію з інститутами громадянського суспільства, здійснення громадського контролю за діяльністю МОЗ, урахування громадської думки під час формування та реалізаиї державної політики у сферах, що належать до компетениї МО3” [18].

Водночас, Міністерство охорони здоров’я України здійснює усталену взаємодію з громадянами і інститутами громадянського суспільства не в складі всього керівництва і всіх підрозділів МОЗ України одночасно (хоча у 2016-2019 рр. керівництво цього міністерства неодноразово безпосередньо спілкувалося з громадськістю, брало участь у різноманітних заходах, як до прикладу Марш рівності в Києві 23 червня 2019 р.), а через спеціально уповноважені підрозділи Міністерство охорони здоров'я України. Подібна публічно-управлінська практика проведення консультацій з громадськістю є характерною для 
всіх органів державного управління в Україні та за кордоном, зокрема, у державах-учасницях і здійснюється в установленому порядку.

В Україні Порядок проведення консультаційзгромадськістюзпитань формування та реалізації державної політики затверджений Постановою Кабінету Міністрів України "Про забезпечення участі громадськості у формуванні та реалізації державної політики" від 3 листопада 2010 року № 996. Метою його регулятивного впливу на громадсько-державні партнерські відносини, як це встановлюе п. 2 цього Положення, є:

"Проведення консультащій з громадськістю має сприяти налагодженню системного діалогу органів виконавчої влади з громадськістю, підвищенню якості підготовки рішень з важливих питань державного $i$ суспільного життя з урахуванням громадської думки, створенню умов для участі громадян у розробленні проектів таких рішень” [19].

Відповідні консультації з громадськістю можуть проводитися за обопільної ініціативи. 3 одного боку, міністерство, яке формує державну політику у визначеній сфері проводить: а) планові, передбачені орієнтовним планом проведення консультацій з громадськістю; б) позапланові, коли ініціативно розробляє проект нормативно-правового акта, який стосується соціально-економічного розвитку держави, утвердження та реалізації конституційних прав і свобод людини, задоволення іï політичних, економічних, соціальних і культурних потреб. 3 іншого боку, відповідно до п. 7 Постанови Уряду України від 3 листопада 2010 р. № 996, інститути громадянського суспільства, а саме, - “... громадські об’єднання, релігійні, благодійні організації, творчі спілки, професійні спілки та їх об'єднання, асоціації, організації роботодавців та їх об'єднання, органи самоорганізації населення, недержавні засоби масової інформації, інші непідприємницькі товариства та установи, легалізовані відповідно до законодавства ...” [19], - самостійно виходять на міністерство з пропозиціями щодо прийняття нормативно-правових актів, які відображують інтереси громадськості в певній сфері державної політики і є предметом громадських консультацій з міністерством, або ж питанням для розгляду громадської ради при міністерстві.

I в першому, і в другому випадках врахування громадської думки при формуванні державної політики у сфері охорони здоров'я та проведення медичної реформи в Україні це завжди спільний результат взаємодії: а) громадськості та інститутів громадянського суспільства, включно з лікарськими асоціаціями, пацієнтськими організаціями etc; б) керівництва Міністерства охорони здоров'я України та керівництва його підрозділів, у першу чергу генеральних директоратів, які і створювалися як основні провайдери медичної реформи в Україні; в) підрозділів Міністерства охорони здоров'я України, які забезпечують постійні комунікації з громадськістю та ін. Зокрема, можна згадати про політичні еліти і бізнес, які, стосовно громадянського суспільства та держави, за влучною оцінкою О. Пухкала, тривалий час “... розвивалися, по суті, паралельно” [10, с. 19]. 
За роки незалежності України підрозділи Міністерства охорони здоров'я України, які здійснюють комунікації з громадянами й інститутами громадянського суспільства пройшли тривалий і малодосліджений у науці публічного управління шлях становлення та розвитку. Так, лише за останні 15 років у складі МО3 України створювались і функціонували наступні підрозділи для комунікацій з громадськістю:

- у 2003 р. - Відділ інформаційно-аналітичного забезпечення, взаємодії з Верховною Радою України та зв'язків з громадськістю;

- у 2005 р. - Відділ інформаційно-аналітичного забезпечення та зв'язків з громадськістю;

- у 2006 р. - Відділ інформаційно-аналітичного забезпечення та зв'язків з громадськістю;

- у 2007 р. - Відділ інформаційно-аналітичного забезпечення, зв'язків з Верховною Радою України та громадськістю;

- у 2008 р. - відділ забезпечення зв'язків з Верховною Радою України та громадськістю Управління програмного, інформаційно-аналітичного забезпечення та зв’язків з Верховною Радою України;

- у 2009-2010 рр. - відділ забезпечення зв'язків з Верховною Радою України та громадськістю Адміністративного департаменту;

- у 2011 р. - Управління стратегічного планування та аналітичного забезпечення взаємодії з Верховною Радою України та зв'язків з громадськістю;

- у 2012 р. - відділ забезпечення зв'язків з Верховною Радою України та громадськістю Департаменту реформ та розвитку галузі охорони здоров'я;

- у 2013 р. - відділ забезпечення зв’язків з Верховною Радою України та громадськістю Департаменту інформаційно-організаційного та документального забезпечення;

- у 2014 р. - відділ комунікацій 3 державними органами і громадськістю та організації доступу до публічної інформації Департаменту організаційного та документального забезпечення;

- у 2015 р. - Управління комунікацій з державними органами і громадськістю;

- із червня 2016 р. і до сьогодні - Відділ забезпечення взаємодії з державними органами та громадськістю і соціального діалогу [11-14].

Узагальнення та аналіз досвіду трансформацій підрозділів Міністерства охорони здоров'я України у XXI ст., уповноважених забезпечувати комунікації з громадянами та інститутами громадянського суспільства при формуванні та реалізації державної політики у сфері охорони здоров’я, дає змогу дійти висновків, що підрозділи комунікацій з громадськістю, навіть враховуючи їх завдання, функції та організаційно-правові форми (самостійні відділи і управління чи відділи у складі управлінь і департаментів МОЗ України) були і залишаються важливими структурними підрозділами Міністерства охорони здоров'я України.

Сформований у 2016 р. й діючий нині в Міністерстві охорони здоров’я України відділ забезпечення взаємодії з державними органами та громадськістю і соціального діалогу відображує увагу керівництва мініс- 
терства до соціального діалогу під час проведення медичної реформи в Україні. Разом з тим, аналіз чинної структури Міністерства охорони здоров’я України, визначеної на його офіційному веб-сайті [20], дає змогу дійти висновку про певну предметно-функціональну роз'єднаність директоратів, які забезпечують проведення медичної реформи в Україні та відділу, що покликаний здійснювати забезпечення взаємодії МОЗ України з громадськістю. У подальшому, на наш погляд, можливим і бажаним було б створення у структурі МO3 України відділу (експертної групи) щодо взаємодії 3 громадськістю у сфері формування та реалізації галузевої державної політики у складі існуючих директоратів. До прикладу, у складі Директорату стратегічного планування та євроінтеграції [16, с. 169-170].

Окрім проаналізованих суб'єктів, які забезпечують участь громадськості у формуванні та реалізації державної політики у сфері охорони здоров'я та проведення медичної реформи, важливим аспектом досліджуваної проблематики є також методи і форми взаємодії Міністерства охорони здоров'я України із громадськістю.

Відповідно до пп. 3, 4, 6 Листа MO3, Міністерство охорони здоров'я України активно запроваджує такі інноваційні форми відкритого діалогу з громадянами і інститутами громадянського суспільства, як електронні консультації з громадськістю щодо проектів актів, прийняття яких ініціює Міністерство. Зокрема, згідно $з$ Наказом МОЗ України “Про затвердження Орієнтовного плану
Міністерства охорони здоров’я України проведення консультацій з громадськістю у 2017 році” від 12 червня 2017 р. № 658 [21], на обговорення громадськості виносились питання щодо: 1) реформування системи охорони здоров'я (створення госпітальних округів, автономізація закладів охорони здоров’я, нових принципів фінансування спеціалізованої та високоспеціалізованої медичної допомоги); 2) закупівлі лікарських засобів, виробів медичного призначення та обладнання за кошти Державного бюджету України; 3) розвитку системи громадського здоров'я; 4) удосконалення системи екстреної медичної допомоги (закупівля автомобілів, обладнання, створення відділень екстреної медичної допомоги, створення оперативно-диспетчерських служб, оснащення автомобілів екстреної медичної допомоги системами GPS-моніторингу та радіозв’язку); 5) стану реалізації програми “Доступні ліки”; 6) виконання з 01.01.2018 р. закладами і установами охорони здоров’я, цілком або частково фінансуються 3 державного та місцевих бюджетів вимог, постанови Кабінету Міністрів України “Деякі питання державного регулювання цін на лікарські засоби і вироби медичного призначення" від 25.03.2017 р. № 333 в частині першочергової закупівлі та забезпечення потреби хворих в лікарських засобах за Національним переліком основних лікарських засобів.

Наказом МОЗ України від 14 лютого 2018 р. № 257 р. затверджено новий Орієнтовний план Міністерства охорони здоров'я України проведення консультацій з громадськістю у 2018 р. [22], реалізація якого сприя- 
ла посиленню діалогу Міністерства з громадськістю, насамперед, у сфері розпочатої масштабної медичної реформи. Хоча, не в усіх випадках громадськість була зацікавлена у проектах нормативно-правових актів, винесених Міністерством охорони здоров'я України на громадське обговорення. До прикладу, пропозиції щодо проекту постанови Кабінету Міністрів України “Про затвердження критеріїв, за якими оцінюється ступінь ризику від провадження господарської діяльності з медичної практики i визначається періодичність проведення планових заходів державного нагляду (контролю) Miністерством охорони здоров’я України”, розміщеного на офіційному-веб сайті цього міністерства з 17 вересня 2018 р. не надходили [23].

Очікувано, що у поточному році Орієнтовний план Міністерства охорони здоров'я України проведення консультацій з громадськістю у 2019 р. також буде введено в дію. Хоча, станом на 01.06.2019 р. він відсутній на офіційному веб-сайті MO3 України у традиційній рубриці “Орієнтовні плани та звіти про проведення консультацій 3 громадськістю”. Це, з поміж іншого, може бути і індикатором пошуку нових методів і форм залучення Міністерством охорони здоров’я України громадськості для консультацій щодо формування та реалізації державної політики у цій медичній сфері.

Усталеною та конструктивною залишається співпраця МО3 України 3 інститутами громадянського суспільства у процесі формування та реалізації державної політики у сфері охорони здоров’я та проведен- ня медичної реформи. Відповідно до п. 7 Листа MO3, такими є такі громадські організацї: Всеукраїнська молодіжна ГО “Студентське братство”; ГО “Українська демократія"; Антикорупційна Громадська Спілка “Совість”; Громадська Спілка “ДЖИЕФ-ЕС-АЙ УКРАЇНА” [11, 12]. На запит цих громадських організацій i відповідно до “Порядку сприяння проведенню громадської експертизи діяльності органів виконавчої влади", затвердженого Постановою Кабінету Міністрів України від 5 листопада 2008 р. № 976 [24], МО3 України успішно провело громадські експертизи за їх запитами. Відповідно, ці партнери МОЗ України залишаються одночасно і партнерами, i “контролерами” ефективності проведення медичних реформ в Україні.

Висновки. Підсумовуючи результати цього дослідження, можна стверджувати, що Міністерство охорони здоров'я відіграє ключову роль у механізмі взаємодії з громадськістю з питань формування та реалізації державної політики у сфері медицини. Ця співпраця, яка в цілому відображує рівень партисипаторної демократії в Україні, на сьогодні систематизовано і репрезентовано двома основними складниками єдиного механізму: 1) нормативно-правовим механізмом як системою нормативно-правових актів, що гарантують право участі громадян в управлінні державними справами, зокрема формування та реалізації державної політики у сфері охорони здоров'я в Україні; 2) організаційно-управлінським механізмом, представленим системою основних акторів у медичній сфері: громадськістю та 
організаційно оформленими інститутами громадянського суспільства, включно з лікарськими асоціаціями, пацієнтськими організаціями etc; керівництвом Міністерства охорони здоров’я України та його підрозділів, насамперед генеральних директоратів, а також підрозділів Міністерства охорони здоров'я України, які забезпечують постійні комунікації з громадськістю.

Очевидно, що організаційно-управлінський механізм залучення громадськості до формування та реалізації державної політики у сфері охорони здоров'я в Україні буде неповним без: а) диференціації інститутів громадянського суспільства в медичній сфері на лікарські організації (асоціації); пацієнтські організації; правозахисні організації, з чітким усвідомленням диференціації інтересів кожної з названих груп громадських організацій; б) розуміння, що повноцінними акторами цієї системи в Україні, прямо чи опосередковано, виступають політичні еліти і представники фінансово-промислових груп, вмонтованих насамперед у фармакологічний бізнес і медично-страховий бізнес, а також бізнесмени, які цілком обгрунтовано вбачають у наданні медичних послуг перспективну підприємницьку діяльність.

\section{СПИСОК ВИКОРИСТАНИХ ДЖЕРЕЛ}

1. Мінцберг $Г$. Міфи про охорону здоров'я. Як не помилитися, реформуючи медичну систему / Г. Мінцберг; пер. з англ. Д. Прокопик. К. : Наш формат, 2019. 232 c.

2. Банчук М. В. Основні проблеми державного управління реформу- ванням галузі охорони здоров'я в Україні : монографія / М. В. Банчук. К. : НАДУ, 2013. 440 c.

3. Медико-соціальні засади публічного врядування у сфері охорони здоров'я : монографія / кол. авторів; за заг. ред. М. М. Білинської, Н. О. Власюк, О. Д. Фірсової. К. : НАДУ, 2018. 416 с.

4. Васюк Н. О. Механізми державного управління підготовкою керівних кадрів для системи охорони здоров’я в Україні / Н. О. Васюк : автореф. дис. ... канд. наук з держ. упр.; спец. 25.00.02 механізми держ. упр. К. : НАДУ, 2013. 20 c.

5. Григорович В. Р. Державне управління процесами підготовки та прийняття управлінських рішень у системі охорони здоров'я України / В. Р. Григорович : автореф. дис. ... канд. наук з держ. упр.; спец. 25.00.02 механізми держ. упр. К. : НАДУ, $2011.20 \mathrm{c}$.

6. Попченко Т. П. Розвиток державно-управлінських механізмів протидії виникненню корупції у сфеpi охорони здоров'я в Україні / Т. П. Попченко : автореф. дис.... канд. наук $з$ держ. упр.; спец. 25.00.02 механізми держ. упр. К. : НАДУ, 2010. $20 \mathrm{c}$.

7. Рингач Н. О. Державне управління охороною здоров'я як складовою забезпечення національної безпеки / Н. О. Рингач : автореф. дис. ... д-ра наук з держ. упр.; спец. 25.00.02 механізми держ. упр. К. : НАДУ, 2010. 36 с.

8. Усаченко Л. М. Теоретико-методологічні засади розвитку взаємовідносин органів державної влади 3 неурядовими організаціями Л. М. Усаченко : автореф. дис. ... д-ра наук з держ. упр.; спец. 25.00.01 теорія та істор. держ. упр. К. : Ін-т законодавства Верховної Ради України, 2009. $32 \mathrm{c}$.

9. Федько О. А. Формування системи суспільних цінностей з покращення 
індивідуального та популяційного здоров'я в Україні / О. А. Федько : автореф. дис. ... д-ра наук з держ. упр.; спец. 25.00.02 механізми держ. упр. К. : НАДУ, 2012. 36 с.

10. Пухкал О. Г. Модернізація системи державного управління в контексті розвитку громадянського суспільства в Україні / О. Г. Пухкал : автореф. дис. ... д-ра наук з держ. упр.; спец. 25.00.01 теорія та істор. держ. упр. К. : НАДУ, 2009. 36 с.

11. Федоренко Т. А. Участь громадськості у формуванні державної політики у сфері охорони здоров'я в Україні та міжнародні стандарти партисипаторної демократії / Т. А. Федоренко // Медико-соціальні засади публічного врядування у сфері охорони здоров'я : монографія / кол. авт. ; за заг. ред. М. М. Білинської, Н. О. Власюк, О. Д. Фірсової. К. : НАДУ, 2018. С. 113.

12. Лист МОЗ України від 03.03.2018 р. № 16-20/Ф-2053/124/2887-зв на звернення гр. Т. А. Федоренко від 07.02.2018 (№ Ф-2053).

13. Fedorenko T. Prawo człowieka do uczęstnictwa w kształtowaniu i realizacji państwowej polityki w zakresie ochrony zdrowia / T. Fedorenko // Ochrona praw człowieka w wymiarze uniwersalnym. Akcjologia - instytucje - nowe wyzwania - praktyka. Red. naukowa J. Jaskiernia, K. Sprzyszak. Toruń: Wydawnictwo Adam Marszałek, 2017. S. 418-421.

14. Федоренко T. А. Щодо взаємодії Мiністерства охорони здоров'я України $з$ громадськістю у сфері проведення медичної реформи / Т. А. Федоренко // Публічне врядування в Україні: стан, виклики та перспективи розвитку : Матеріали щорічної Всеукр. наук.-практ. конф. за міжнар. участю, присвяченої 100-річчю держ. служби в Україні (м. Київ, 25 трав. 2018 р.) : у 5 т. / за заг. ред.
В. С. Куйбіди, М. М. Білинської, О. М. Петроє. К. : НАДУ, 2018. Т. 5. C. 117-118.

15. Федоренко T. А. Трансформація підрозділів Міністерства охорони здоров’я України, відповідальних за зв’язки з громадськістю у сфері формування та реалізації державної політики в галузі медицини / Т. А. Федоренко // Інституціоналізація публічного управління в Україні в умовах євроінтеграційних та глобалізаційних викликів : матеріали щорічної Всеукр. наук.-практ. конф. за міжнар. участю (Київ, 24 трав. 2019 р.) : у 5 т. / за заг. ред. А. П. Савкова, М. М. Білинської, О. М. Петроє. К. : НАДУ, 2019. С. 95-97.

16. Федоренко T. A. Щодо розвитку підрозділів Міністерства охорони здоров'я України, уповноваженого забезпечувати комунікаціїз громадськістю у контексті проведення медичноїреформи / Т.А. Федоренко / / Актуальні проблеми державно-правового розвитку України в контексті інтеграційних процесів: матеріали IV-ї Міжнародної наук.-практ. конф. (Запоріжжя, 18 трав. 2019 р.) / редкол.: С. К. Бостан, Р. М. Максакова, Т. С. Леоненко. Дніпро : ЛІРА ЛТД, 2019. С. 167-170.

17. Про центральні органи виконавчої влади : Закон України від 17 березня 2011 р. // Відомості Верховної Ради України. 2011. № 38. Ст. 385.

18. Положення про Міністерство охорони здоров'я України: Постанова Кабінету Міністрів України від 25 березня 2015 р. № 267 // Офіц. вісн. України. 2015. № 38. Ст. 1141.

19. Про забезпечення участі громадськості у формуванні та реалізації державної політики : Постанова Кабінету Міністрів України від 3 листоп. 2010 р. № 996 // Офіц. вісн. України. - 2010. - № 84. - Ст. 2945. 
20. Структура Міністерства охорони здоров'я України // Офіц. веб-сайт MO3 України [Електронний ресурс]. - Режим доступу: http://moz. gov.ua/struktura\#!popup-70 (назва 3 екрана).

21. Про затвердження Орієнтовного плану Міністерства охорони здоров’я України проведення консультацій з громадськістю у 2017 році: Наказ МОЗ України від 12 червня 2017 р. № 658 [Електронний ресурс]. - Режим доступу: http://old. moz.gov.ua/ua/portal/pk_20170612. html (назва з екрану).

22. Про затвердження Орієнтовного плану Міністерства охорони здоров’я України проведення консультацій з громадськістю у 2017 році: Наказ МОЗ України від 14 лютого 2018 р. № 257 р. [Електронний peсурс]. Режим доступу: http:// moz.gov.ua/orientovni-plani-tazviti-pro-provedennja-konsultacijz-gromadskistju-1 (назва з екрану).

23. Звіт про громадське обговорення проекту постанови Кабінету Міністрів України "Про затвердження критеріїв, за якими оцінюється ступінь ризику від провадження господарської діяльності 3 медичної практики i визначається періодичність проведення планових заходів державного нагляду (контролю) Міністерством охорони здоров’я України" // Офіц. веб-сайт МОЗ України [Електронний ресурс]. Режим доступу: http:// moz.gov.ua/uploads/ckeditor/\%D0\%9 3\%D1\%80\%D0\%BE\%D0\%BC\%D0\% B0\%D0\%B4\%D1\%81\%D1\%8C\%D0 \%BA\%D0\%B5\%20\%D0\%BE\%D0\%B 1\%D0\%B3\%D0\%BE\%D0\%B2\%D0\% BE\%D1\%80\%D0\%B5\%D0\%BD\%D0 $\% \mathrm{BD} \% \mathrm{D} 1 \% 8 \mathrm{~F} /$ Zvit_pro_gromadske obgovorennya_20181130-2.pdf (назва з екрану).

24. Про затвердження Порядку сприяння проведенню громадської експер- тизи діяльності органів виконавчої влади : Постанова Кабінету Міністрів України від 5 листопада 2008 р. № 976 // Офіц. вісн. України. 2008. № 86. Ст. 100.

\section{REFERENCES}

1. Mintzberg H. (2019). Mify pro okhoronu zdorovia. Yak ne pomylytysia, reformuiuchy medychnu systemu [Managing the Myths of Health Care: Bridging the Separations between Care, Cure, Control, and Community]. (D. Prokopyk, Trans). Kyiv: Nash format [in Ukrainian].

2. Banchuk M. V. (2013). Osnovni problemy derzhavnoho upravlinnia reformuvanniam haluzi okhorony zdorovia $\checkmark$ Ukraini [The main problems of public administration reform in the healthcare sector in Ukraine]. Kyiv: NADU [in Ukrainian].

3. Bilynska M. M., Vlasiuk N. O., Firsova O. D. (Eds.). (2018). Medyko-sotsialni zasady publichnoho vriaduvannia u sferi okhorony zdorovia [Medical social principles of public administration in the field of health]. Kyiv: NADU [in Ukrainian].

4. Vasiuk N. O. (2013). Mekhanizmy derzhavnoho upravlinnia pidhotovkoiu kerivnykh kadriv dlia systemy okhorony zdorovia v Ukraini [Mechanisms of Public Administration for the Training of Managers for the Health Care System in Ukraine]. Extended abstract of candidate's thesis. Kyiv: NADU [in Ukrainian].

5. Hryhorovych V. R. (2011). Derzhavne upravlinnia protsesamy pidhotovky ta pryiniattia upravlinskykh rishen $\mathrm{u}$ systemi okhorony zdorovia Ukrainy [Public administration of the processes of preparation and acceptance of managerial decisions in the system of public health in Ukraine]. Extended abstract of candidate's thesis. Kyiv: NADU [in Ukrainian]. 
6. Popchenko T. P. (2010). Rozvytok derzhavno-upravlinskykh mekhanizmiv protydii vynyknenniu koruptsii u sferi okhorony zdorovia v Ukraini [Development of state-management mechanisms for combating corruption in the healthcare sector in Ukraine]. Extended abstract of candidate's thesis. Kyiv: NADU [in Ukrainian].

7. Rynhach N. O. (2010). Derzhavne upravlinnia okhoronoiu zdorovia yak skladovoiu zabezpechennia natsionalnoi bezpeky [Public health management as a component of national security]. Extended abstract of Doctor's thesis. Kyiv: NADU [in Ukrainian].

8. Usachenko L. M. (2009). Teoretykometodolohichni zasady rozvytku vzaiemovidnosyn orhaniv derzhavnoi vlady $\mathrm{z}$ neuriadovymy orhanizatsiiamy [Theoretical methodological principles of development of relations of state authorities with non-governmental organizations]. Extended abstract of Doctor's thesis. Kyiv: Inst. zak-va Verkhovnoi Rady Ukrainy [in Ukrainian].

9. Fedko O. A. (2012). Formuvannia systemy suspilnykh tsinnostei z pokrashchennia indyvidualnoho ta populiatsiinoho zdorovia $\mathrm{v}$ Ukraini [Formation of a system of public values for the improvement of individual and population health in Ukraine]. Extended abstract of Doctor's thesis. Kyiv: NADU [in Ukrainian].

10. Pukhkal O. H. (2009). Modernizatsiia systemy derzhavnoho upravlinnia $\mathrm{v}$ konteksti rozvytku hromadianskoho suspilstva v Ukraini [Modernization of the public administration system in the context of the development of civil society in Ukraine]. Extended abstract of Doctor's thesis. Kyiv: NADU [in Ukrainian].

11. Fedorenko T. A. (2018). Uchast hromadskosti u formuvanni derzhavnoi polityky u sferi okhorony zdorovia $\mathrm{v}$
Ukraini ta mizhnarodni standarty partysypatornoi demokratii [Public Participation in the Formation of Public Health Policy in Ukraine and International Standards for Participatory Democracy]. Medyko-sotsialni zasady publichnoho vriaduvannia $u$ sferi okhorony zdorovia - Medical social principles of public administration in the field of health. M. M. Bilynska, N. O. Vlasiuk, O.D. Firsova (Eds.). (p. 113). Kyiv: NADU [in Ukrainian].

12. Lyst MOZ Ukrainy vid 03.03.2018 r. \# 16-20/F-2053/124/2887-zv na zvernennia hr. T. A. Fedorenko vid 07.02.2018 (\# F-2053) [Letter from the Ministry of Health of Ukraine dated March 3 2018, № 16-20 / F2053/124/2887-zn on the treatment of T. A. Fedorenko from 02.07.2018 (№ F-2053)]. [in Ukrainian].

13. Fedorenko T. (2017). Prawo człowieka do uczęstnictwa w kształtowaniu i realizacji państwowej polityki w zakresie ochrony zdrowia. Ochrona praze czlowieka w wymiarze uniwersalnym. Akcjologia - instytucje - nоже тoyzwania - praktyka. J. Jaskiernia, K. Sprzyszak (Eds.). (p. 418-421). Toruń: Wydawnictwo Adam Marszałek [in Polish].

14. Fedorenko T. A. (2018). Shchodo vzaiemodii Ministerstva okhorony zdorovia Ukrainy $\mathrm{z}$ hromadskistiu u sferi provedennia medychnoi reformy [Concerning the interaction of the Ministry of Health of Ukraine with the public in the field of medical reform]. Publichne vriaduvannia v Ukraini: stan, oyklyky ta perspektyoy rozoytku - Public Governance in Ukraine: State, Challenges and Development Prospects: Proceedings from annual All-Ukrainian scientific practical conference with international participation devoted to the $100^{\text {th }}$ anniversary of the State Service in Ukraine. V. S. Kuibida, M. M. Bilynska, 
O. M. Petroie (Eds.). (Vols. 5). (p.117118). Kyiv: NADU [in Ukrainian].

15. Fedorenko T. A. (2019). Transformatsiia pidrozdiliv Ministerstva okhorony zdorovia Ukrainy, vidpovidalnykh za zviazky z hromadskistiu u sferi formuvannia ta realizatsii derzhavnoi polityky $\mathrm{v}$ haluzi medytsyny [Transformation of the units of the Ministry of Health of Ukraine, which are responsible for public relations in the field of the formation and implementation of state policy in the field of medicine]. Instytutsionalizatsiia publichnoho upravlinnia v Ukraini $v$ umovakh yevrointehratsiinykh ta hlobalizatsiinykh oykdykiv - Institutionalization of public administration in Ukraine in the context of European integration and globalization challenges: Proceedings from annual All-Ukrainian scientific practical conference with international participation. A. P. Savkov, M. M. Bilynska, O. M. Petroie (Eds.). (p. 95-97). Kyiv: NADU [in Ukrainian].

16. Fedorenko T. A. (2019). Shchodo rozvytku pidrozdiliv Ministerstva okhorony zdorovia Ukrainy, upovnovazhenoho zabezpechuvaty komunikatsii z hromadskistiu v konteksti provedennia medychnoi reformy [Concerning development of units of the Ministry of Health of Ukraine authorized to provide public relations in the context of medical reform]. Aktualni problemy derzhavno-pravovoho rozoytku Ukrainy v konteksti intehratsiinykh protsesiv Actual Problems of State-Legal Development of Ukraine in the Context of Integration Processes: Proceedings from the $4^{\text {th }}$ International Scientific and Practical Conference. S. K. Bostan, R. M. Maksakov, T. Ye. Leonenko (Eds.). (p. 167-170). Dnipro: LIRA LTD [in Ukrainian].

17. Zakon Ukrainy "Pro tsentralni orhany vykonavchoi vlady" : vid 17 bereznia 2011 r. [Law of Ukraine "On central executive authorities": from March 17 2011]. (2011). Vidomosti Verkhoonoi Rady Ukrainy - Bulletin of Verkhowna Rada of Ukraine, 38 [in Ukrainian].

18. Postanova Kabinetu Ministriv Ukrainy "Polozhennia pro Ministerstvo okhorony zdorovia Ukrainy" vid 25 bereznia 2015 r., № 267 [Resolution of the Cabinet of Ministers of Ukraine "Regulation on the Ministry of Health of Ukraine" from March 25 2015, № 267]. (2015). Ofitsiinyi visnyk Ukrainy Official Bulletin of Ukraine, 38 [in Ukrainian].

19. Postanova Kabinetu Ministriv Ukrainy "Pro zabezpechennia uchasti hromadskosti u formuvanni ta realizatsii derzhavnoi polityky" : vid 3 lystopada 2010 roku, № 996 [Resolution of the Cabinet of Ministers of Ukraine "On ensuring public participation in the formation and implementation of state policy" from November 32010 , № 996]. (2010). Ofitsiinyi visnyk Ukrainy - Official Bulletin of Ukraine, 84 [in Ukrainian].

20. Struktura Ministerstva okhorony zdorovia Ukrainy [Structure of the Ministry of Health of Ukraine]. moz. gov.ua. Retrieved from http://moz.gov. ua/struktura\#!popup-70 [in Ukrainian].

21. Nakaz MOZ Ukrainy "Pro zatverdzhennia Oriientovnoho planu Ministerstva okhorony zdorovia Ukrainy provedennia konsultatsii $\mathrm{z}$ hromadskistiu u 2017 rotsi” vid 12 chervnia 2017 r., № 658 [Order of the Ministry of Health of Ukraine "On the approval of the Tentative Plan of the Ministry of Health of Ukraine for holding consultations with the public in 2017" from June 12 2017, № 658]. (n.d.). old.moz. gov.ua. Retrieved from http://old.moz. gov.ua/ua/portal/pk_20170612.html [in Ukrainian].

22. Nakaz MOZ Ukrainy "Pro zatverdzhennia Oriientovnoho planu Minister- 
stva okhorony zdorovia Ukrainy provedennia konsultatsii z hromadskistiu u 2017 rotsi" : vid 14 liutoho 2018 r., № 257 [Order of the Ministry of Health of Ukraine "On Approval of the Tentative Plan of the Ministry of Health of Ukraine to hold consultations with the public in 2017" from February 14 2018, № 257]. (n.d.). old. moz.gov.ua. Retrieved from http:// moz.gov.ua/orientovni-plani-ta-zvitipro-provedennja-konsultacij-z-gromadskistju-1 [in Ukrainian].

23. Zvit pro hromadske obhovorennia proektu postanovy Kabinetu Ministriv Ukrainy "Pro zatverdzhennia kryteriiv, za yakymy otsiniuietsia stupin ryzyku vid provadzhennia hospodarskoi diialnosti z medychnoi praktyky i vyznachaietsia periodychnist provedennia planovykh zakhodiv derzhavnoho nahliadu (kontroliu) Ministerstvom okhorony zdorovia Ukrainy" / ofitsiinyi veb-sait MOZ Ukrainy [Report on public discussion of the draft resolution of the Cabinet of Ministers of Ukraine "On Approval of the criteria for assessing the degree of risk from conducting business activities in medical practice and determining the frequency of planned state supervision (control) by the Ministry of Health of Ukraine"]. (n.d.). moz.gov. ua. Retrieved from http://moz.gov.ua/ uploads/ckeditor/\%D0\%93\%D1\%80 $\%$ D0\%BE\%D0\%BC\%D0\%B0\%D0\% B4\%D1\%81\%D1\%8C\%D0\%BA\%D0 $\%$ B5\%20\%D0\%BE\%D0\%B1\%D0\%B $3 \% \mathrm{D} 0 \% \mathrm{BE} \% \mathrm{D} 0 \% \mathrm{~B} 2 \% \mathrm{D} 0 \% \mathrm{BE} \% \mathrm{D} 1$ $\% 80 \% \mathrm{D} 0 \% \mathrm{~B} 5 \% \mathrm{D} 0 \% \mathrm{BD} \% \mathrm{D} 0 \% \mathrm{BD} \%$ D1\%8F/Zvit_pro_gromadske_obgovorennya_20181130-2.pdf [in Ukrainian].

24. Postanova Kabinetu Ministriv Ukrainy "Pro zatverdzhennia Poriadku spryiannia provedenniu hromadskoi ekspertyzy diialnosti orhaniv vykonavchoi vlady" : vid 5 lystopada 2008 roku, № 976 [Resolution of the Cabinet of Ministers of Ukraine "On Approval of the Procedure for Facilitating the Public Examination of the Activities of Executive Bodies” from November 5 2008, № 976]. (2008). Ofitsiinyi visnyk Ukrainy Official Bulletin of Ukraine, 86 [in Ukrainian]. 